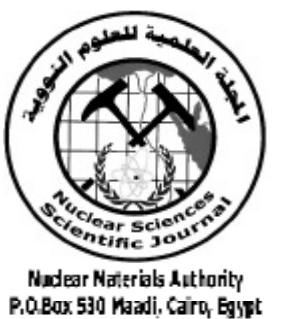

ISSN 2314-5609

Nuclear Sciences Scientific Journal

$5,15-32$

2016

http://www.ssnma.com

\title{
GEOLOGY, PETROGRAPHY, GEOCHEMISTRY AND RADIOACTIVITY STUDIES ON THE DYKE SWARMS OF GABAL AL AGLAB AREA, NORTH EASTERN DESERT, EGYPT
}

\author{
MOHAMED M. M. EL DABE \\ Nuclear Material Authority, P.O. Box 530 Maadi, Cairo, Egypt.
}

\begin{abstract}
Gabal Al Aglab area is located in the North Eastern Desert of Egypt bounded by lat. $27^{\circ} 14^{\prime}-27^{\circ} 19^{\prime} \mathrm{N}$ and long. $33^{\circ} 00^{\prime}-33^{\circ} 05^{\prime} \mathrm{E}$. It is covered by pan African basement rocks. The present study concern with the geology, petrography, geochemistry and radioactivity of various types of the dyke swarms in Gabal Al Aglab area. The field studies revealed that the area comprises the following litho-tectonic units ; Dokhan volcanic (oldest) and Hamammat sedimentary rocks and younger granites are represented by both Gabal Um Twier and Gabal Al Aglab syenogranites (youngest). Many dykes of acidic, intermediate and basic composition have a large extension and dissect all the mentioned rock units.

The dyke swarms intruding Gabal Al Aglab area include the acidic (felsite and granite porphyry) dykes, while the intermediate comprise andesite and andesite porphyry and the basic dykes show basalt and dolerites. The chronologic relations of these dykes indicate the following sequence of emplacement beginning with the oldest acidic, followed by intermediate and then basic ones.

The geochemical studies indicate that the acidic dykes were derived from a highly differentiated calcalkaline magma, while the basic and intermediate dykes were developed from magma of subalkaline nature. The dykes were derived from separate magmas and not by magmatic differentiation of single mother magma.

The radioactivity of the studied dyke rocks revealed that the high levels of radioactivity mainly linked to the acidity, differentiation and alkalinity characters. Radioactive granitic spot was observed along the contact with some basic dykes due to their thermal effect during its emplacement on the granite, at the northern part of the studied area. This radioactive spot display anomalies with higher values in $\mathrm{U}$ and $\mathrm{Th}$ contents, than the normal background value of the younger granite.
\end{abstract}

\section{INTRODUCTION}

The dyke swarms are intruding Gabal Al Aglab area and are founding as the one of the most plentiful dyke swarms in the north Eastern Desert of Egypt. Several authors studied the Gabal Al Aglab area representing a part of the Red Sea Hills of the north Eastern Desert of Egypt. These dykes are equivalent and pertain to the post-granitic dykes, Amin et al.
(1954), El-Ramly and Akaad (1960), Ayoub (2003) and El-Sawey et al. (2009). According to Stern et al. (1984 and 1988), these dykes demonstrate the extensional tectonic regime which dominated the north eastern crustal evolution. In respect to the mechanism of dyke formation, it is thought that these dykes probably occupied fractures under tensional forces operating in the region (Kabesh and 
Shahin, 1968). Stern and Hedge (1985) reported $\mathrm{Rb}$-Sr ages for some dykes in the north Eastern Desert ranging between 543 and 589 Ma. The study area is covered by moderate to high elevated hills of rugged topography. The topographic features of this area are mainly controlled by both the structural and the lithologic characteristics of each rock type. The studied area is located between lat. $27^{\circ} 14^{\prime}-$ $27^{\circ} 19^{\prime} \mathrm{N}$ and long. $33^{\circ} 00^{\prime}-33^{\circ} 05^{\prime} \mathrm{E}$, situated about $120 \mathrm{~km}$ northwest of Hurgada City and covered about $73 \mathrm{~km}$. (Fig. 1). It is covered by Precambrian rocks comprising from older to younger; Dokhan volcanic, Hamammat sedimentary rocks, and younger granites G. Um Twier and G. Al Aglab syenogranites (Akaad et al., 1979; Abu El Lile 1980; Rogers and Greenberg 1983 and Ayoub 2003). Many dyke swarms of acidic, intermediate and basic composition have large extension and dissect all the mentioned rock units.

The present work deals with the geology, petrography, geochemistry and radioactivity of various types of the dyke swarms intruding the Gabal Al Aglab area.

\section{GEOLOGIC SETTING}

The dyke swarms in Gabal Al Aglab area comprise felsites, granite porphyry, andesite, andesite porphyry, basalt and dolorite dykes. These dykes cut all the rock exposures covering the area. These rocks include Dokhan volcanic, Hammamat sedimentary rocks and the younger granites. In the studied area, the dyke suites were emplaced along the prevailing NE-SW and ENE-WSW weak zones; more commonly the former one. They extend in E-W and N-S directions and they rarely extend in NNE-SSW and NNW-SSE directions (Fig. 2). So, these dykes could be structurally grouped into four main sets trending NE-SW, ENE-WSW, E-W and N-S.

The investigated area is affected by the Red Sea Graben. Thus, the direction of some studied faults and joints are parallel or subparallel to Red Sea and Gulf of Suez, i.e. of synthetic nature, the others are not parallel neither to Red Sea nor Gulf of Suez, i.e. antithetic natures. All the representative studied dykes are perpendicular or sub-perpendicular to the direction of Red Sea axis and the Gulf

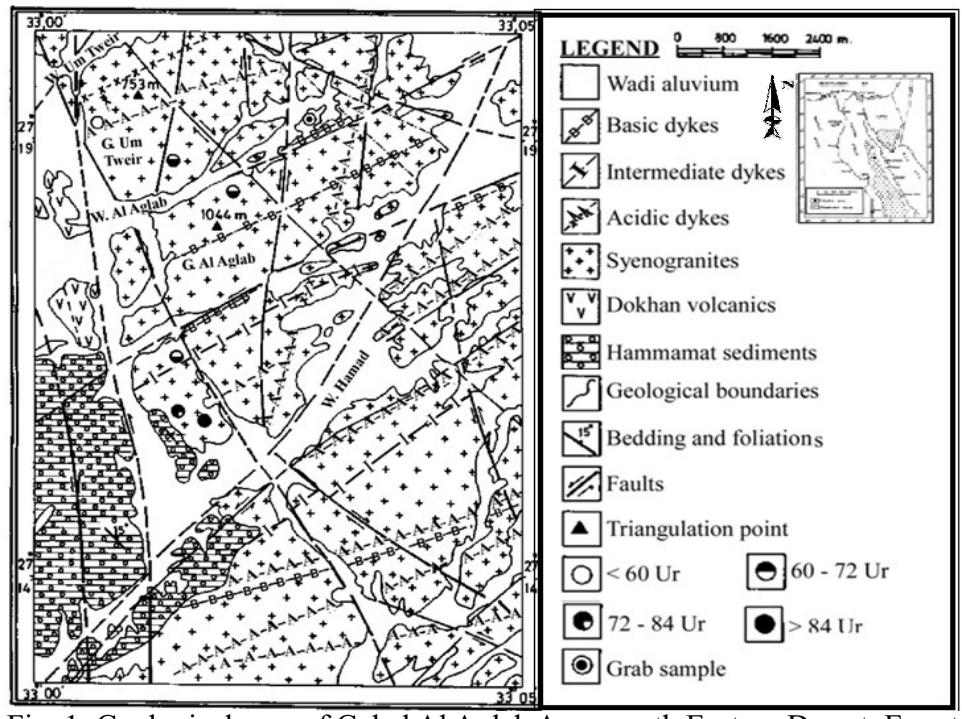

Fig. 1: Geological map of Gabal Al Aglab Area, north Eastern Desert, Egypt, (Modified after Ayoub, 2003) 


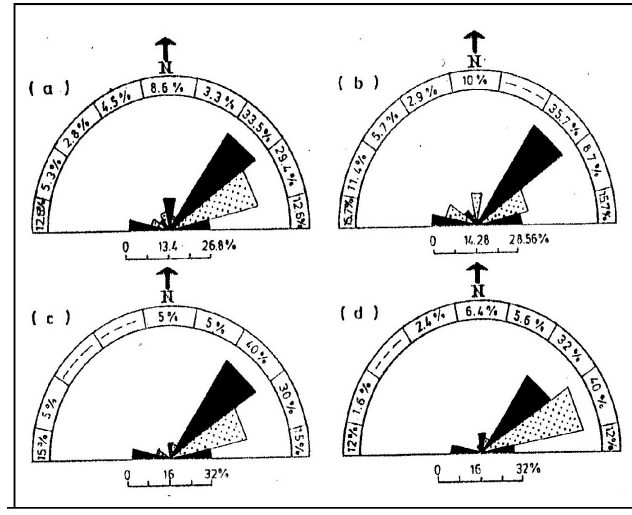

Fig. 2: Rose diagram showing the main directional trends of different dykes (a), different acidic dykes (b), intermediate dykes (c) and basic dykes (d), based on their number proportion, GabalAl Aglab area

of Suez, i.e filling the antithetic fractured zone.

The predominant dykes recorded in the study area trend NE-SW and ENE-WSW run in parallel to sub-parallel swarms and follow the prevailing structural system. These dykes are represented the late magmatic derivation after the emplacement of the granitic masses, and are considered as the immediate successor of the younger granite intrusion. They are ranging in composition from acidic, intermediate to basic varieties. In Gabal Al Aglab area, the majority of the dykes generally run in parallel to sub-parallel swarms. They are controlled, in most cases, by the prevailing fractures, faults, and shear zones. The NESW and ENE-WSW directions represent the most predominating trend of these dykes followed by the E-W and N-S trends. These results are confirmed with El Shazly (1970), who concluded that most of the intruded dykes are governed and controlled by major fault systems. The dykes intruding the country rocks form discontinuous rectilinear, less commonly very gently curved outcrops, and are vertical to sub-vertical. They are ranging in thickness from $0.5 \mathrm{~m}$ up to $15 \mathrm{~m}$ and can be traced for tens of kilometers.
Their field relations show that the basic dykes cut both the acidic and intermediate dykes, while the relation of the intermediate dykes with the acidic dykes were not observed. Thus they can be chronologically arranged as follows, from oldest to youngest.

A- Basic dykes: include basalts and dolerites. ...(Youngest)

B-Intermediate dykes : include andesite and andesite porphyries

C- Acidic dykes: include felsites and granite porphyries.

(Oldest)

\section{Acidic Dykes}

These dykes are the most abundant and widely distributed in the study area. This group includes the felsites and the less abundant granite porphyries. Generally, they exceed $4 \mathrm{~m}$ in thickness and can reach up to 15 $\mathrm{m}$, having steep walls and sharp contact with the host rocks. The interrelation between different acidic dyke varieties is not clear. They are usually parallel to each other (Fig. $3)$. From the relations proved from similar nearby area, the felsites are older than the granite porphyries (Shazly, 1964). They are more resistant to erosion than their enclosing country rocks.

Felsites are widely distributed and cut all the rock types in Gabal Al Aglab area. They

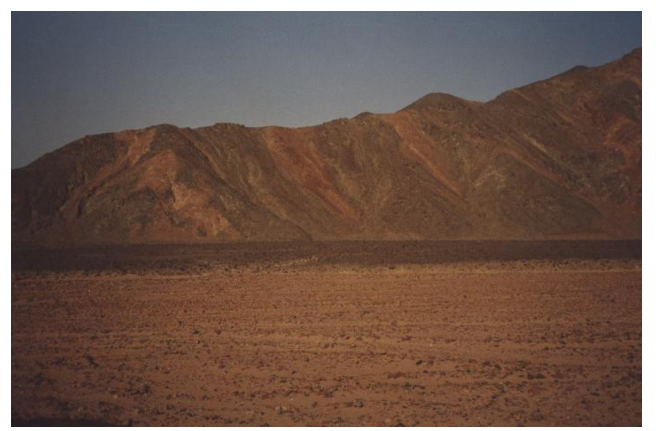

Fig. 3:A set of acidic dyke swarms striking N40 $\mathrm{E}$ in the Dokhan volcanics, Gabal Al Aglab area, looking $\mathrm{S}$ 
are represented by thick and long dykes running in sub-parallel sets. Felsite dykes are hard and high resistant to erosion, so they can be easily traced on aerial photographs for long distances, and hence they form ribbonlike elongated ridges exhibiting back-bone feature (Fig. 4). The felsites dykes are fine to very fine grained, massive and varying in color from buff, pink, dark pink, brownish pink, pale brown to red. The felsitic dykes are mainly predominating in the NE-SW directions.

Petrographically, felsite dykes are the most abundant dykes cutting throughout the mapped area. Generally, they are fine-grained to cryptocrystalline. They are chiefly composed of fine-grained holocrystalline felsitic groundmass of quartz, plagioclase and potash feldspar with subordinate interstitial shreds of biotite, muscovite and chlorite. The groundmass encloses some spherulitic and micrographic intergrowths of quartz and feldspars and is spotted with iron oxides (Fig. 5).

Granite porphyry dykes are less abundance among the acidic dykes in the study area. They are cutting all the rock types of G. Al Aglab area. They are usually large in thickness, straight, vertical and have pinkish to dark red colors. They are hard and massive rocks composed of large phenocrysts of $\mathrm{K}$-feldspars, quartz with mafics embedded in

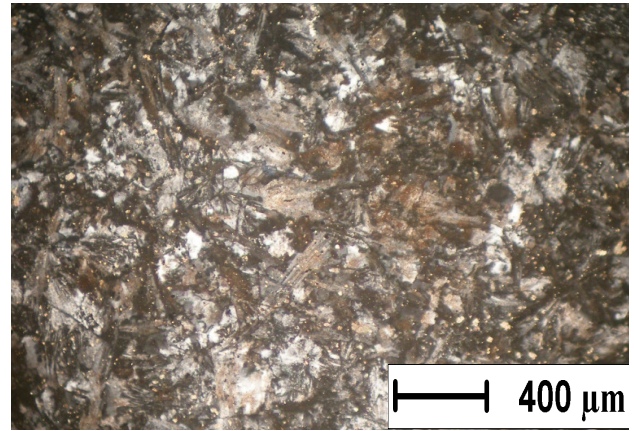

Fig. 5: General view of fine-grained holocrystalline groundmass of quartz, plagioclase and potash feldspar in felsite dykes,

a pinkish red cryptocrystalline matrix of granitic composition.

Generally, the dykes are of simple type, although multiple and composite dykes are sometimes recorded (Fig.6). Multiple dykes are composed of two successive injections of the same type of magma. Composite dykes are composed of two neighbor contrasting rock types. Some fractures filled with acidic dykes show rejuvenation by emplacement of basic dykes at the core and surrounded at both sides with the acidic dyke forming composite dykes.

Granite porphyry dykes are closely asso-

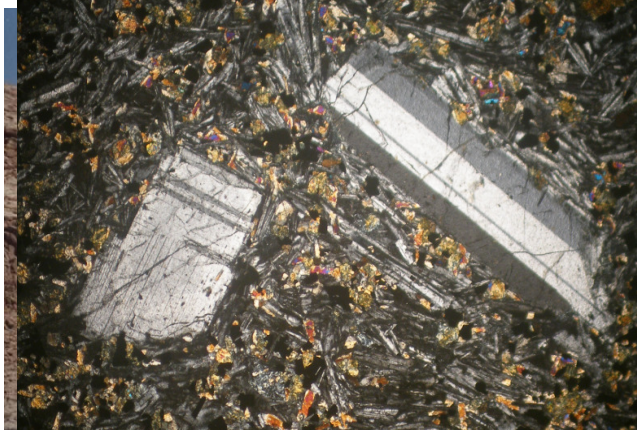

Fig. 6: The granitic porphy dykes (A) form ribbonlike elongated ridges exhibiting back-bone feature, while the basic dykes (B) in the core form deep elongated trenches in their host rocks, Gabal Al Aglab area, looking E
Fig. 4: felsites dykes show highly resistant to erosion, forming parallel protruding ridges and spines, Gabal Al Aglab area, looking NNE 
ciated with the granites and are considered to be genetically related. They are composed of potash feldspar, quartz and plagioclase feldspar phenocrysts of variable grain size, embedded in a quartzo-feldspathic groundmass. Chlorite and sericite are recorded as secondary minerals, iron-oxides; zircon and sphene represent the accessory minerals (Fig.7).

\section{Intermediate Dykes}

These dykes are less abundant and of limited distribution in the study area, and mainly cut through all the older rock types. They can be easily traced when traversing the granitic rocks, whereas they are hardly seen within the volcanic rocks. These dykes run in the NESW direction in parallel to sub-parallel sets. They are usually vertical or steeply inclined and intruded in sharp contacts with their host rocks. These dykes are mainly andesite and andesite porphyries, fine-grained, hard and massive rocks of greyish green to brownish green color. These andesites and its andesite porphyry dykes attain a uniform thickness of about $3 \mathrm{~m}$ and have phenocrysts of plagioclase laths embedded in a fine-grained green matrix. These dykes are suffering from the weathering effects and form deep elongated trenches in their host rocks (Fig. 8). Occasionally, angular fragments of younger gran-

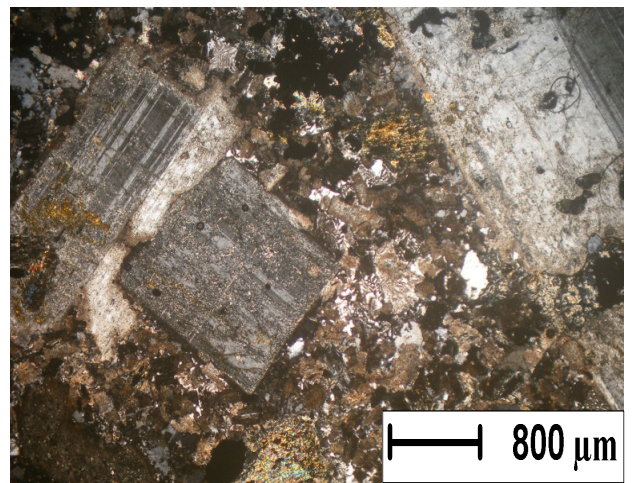

Fig. 7: Potash feldspar, quartz and plagioclase feldspar phenocrys of variable grain size, embedded in a quartzo-feldspathic groundmass in granite porphyry dykes

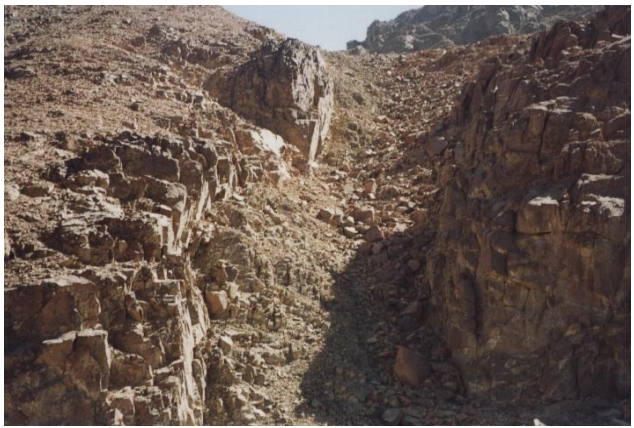

Fig. 8: Deep elongated trench formed by a highly weathered intermediate dyke, Gabal Al Aglab area, looking NE

ites are observed in the intermediate dykes as xenoliths. Petrographically, the andesite dykes include andesites (Fig. 9) and their andesite porphyries (Fig. 10). They are medium- to fine-grained, hard and massive rocks of greyish green to brownish green color. Occasionally; they have porphyritic plagioclase laths in a fine-grained green matrix.

They are essentially composed of plagioclase (andesine), hornblende, biotite with subordinate quatz and chlorite (Fig. 10).

\section{Basic Dykes}

These dykes are most abundant dyke rocks in the investigated area. They are rep-

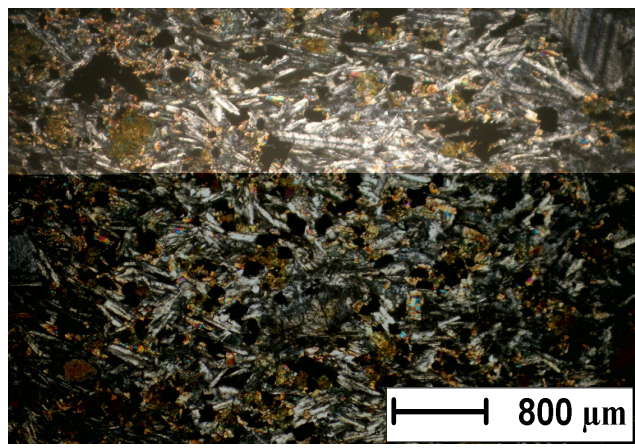

Fig. 9: P lagioclase, hornblende, biotite phenocrysts embedded in quatzo-feldspathic groundmass and chlorite in andesite dykes 


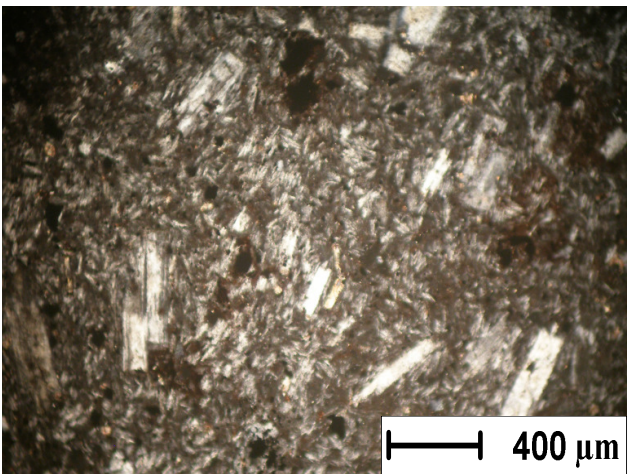

Fig. 10: Porphyritic plagioclase laths embedded in a fine-grained matrix of andesite porphyry dykes

resented by dykes of basaltic and doleritic composition. They penetrate all rock types and are dark green in color, fine to very finegrained, massive and hard. The majority of these dykes have a tendency to form parallel to sub-parallel swarms because they are structurally controlled, and occasionally display multiply bifurcated type (Figs. 11\&12). They are commonly found along some faults and major fractures ranging in thickness from $20 \mathrm{~cm}$ to about $10 \mathrm{~m}$, and extend for several kilometers.

Basic dykes are usually less resistant to erosion than their invaded rocks especially those cutting through the hard granitic rocks,

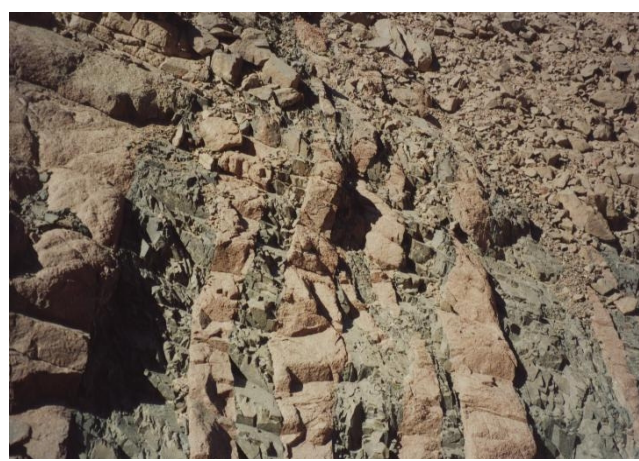

Fig. 11:A set of basic dyke swarms following NESW trend, Gabal Al Aglab area, looking NE

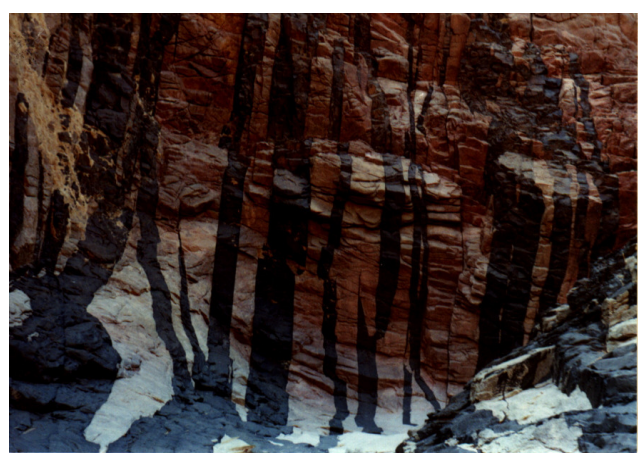

Fig. 12: Simple and multiple basic dyke types run in parallel to sub-parallel sets controlled by the predominating faults of the area, Gabal Al Aglab area, looking $\mathrm{N}$

and form deep elongated trenches. They show characteristic onion like weathering (Fig. 13), with colors varying from dark green to greenish black and black. The majority of these dykes follow the NE-SW direction in straight form. However, they occasionally show curvilinear orientation. Moreover, they are steep to vertical inclination $\left(75^{\circ}-90^{\circ}\right)$, with sharp contacts and sometimes they send narrow apophyses into the host rocks.

Petrographically, the basic dykes are massive, fine-grained; they are of dark grey to deep green color. These basic dykes are mainly represented by basalts and dolerites. Basalt dykes are fine- to very fine-grained, massive and of deep green to black colour. They are essentially composed of plagioclase, hornblende and pyroxene. Opaques and apatite are the main accessories (Fig. 14). Dolerite dykes are mainly consisted of plagioclase and pyroxene with subordinate hornblende, while opaques are the main accessories, and display diabasic texture (Fig. 15). They are medium grained and greenish grey to blackish green in color.

Finally, according to the cross-cutting relationships it was possible to deduce the following chronologic sequence of emplacement for the present dyke swarms beginning with the oldest; acidic, intermediate and basic. In 


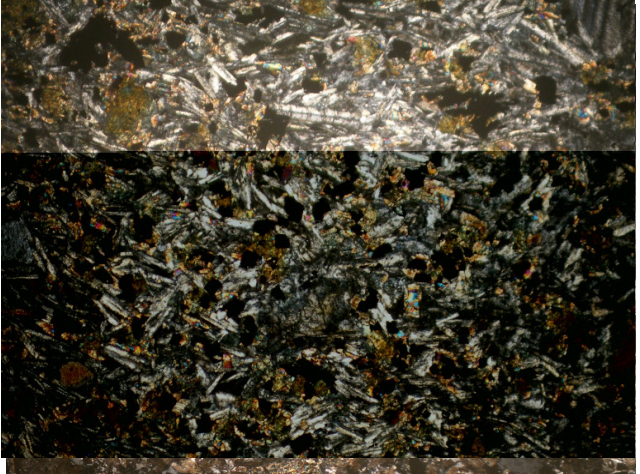

Fig. 13: Onion-like weathering exhibited in a basaltic dyke, Gabal Al Aglab area, looking NE

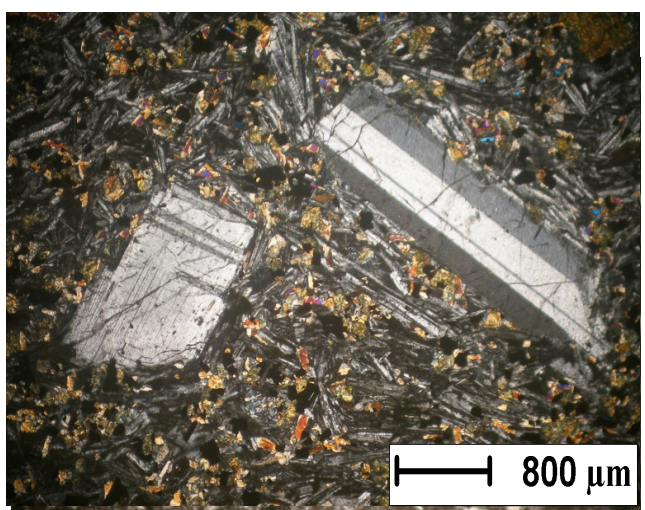

Fig. 14: Large crystal of plagioclase, hornblende and pyroxene embedded in fine grained of plagioclase, hornblend and opaque, basaltic dykes

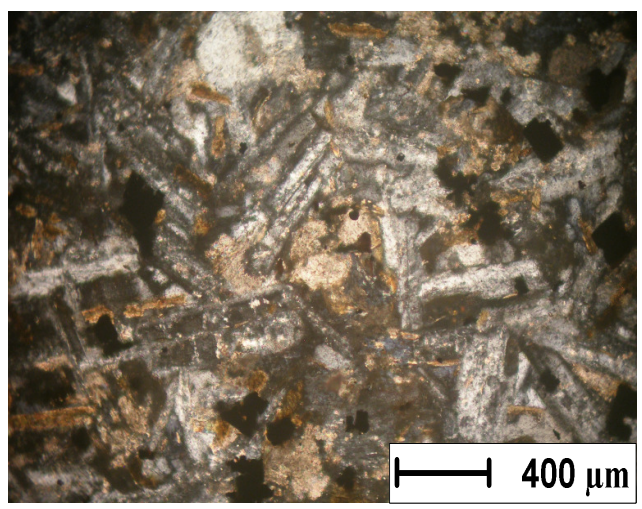

Fig. 15: Plagioclase and pyroxene with subordinate hornblende, form the diabasic texture, dolorite dykes the studied area, the basic dyke cuts the acidic one in a clear field cross cut relationship (Fig.16). However, Abu El Lile (1980) stated that the following sequence for the post-granite dykes of G. Al Aglab beginning with the oldest; acidic, intermediate, basic and alkaline. Roz (2001) recognized only three varieties among the G. Al Aglab dyke swarms which are arranged according to the sequence of their emplacement in the field as acidic, intermediate and basic. Ayoub (2003) deduced the following relative timing for G. Al Aglab dyke swarms, beginning with the oldest; acidic, intermediate and basic; coincide with nearby area of Gabal Abu Harba (Mohamed, 2013). Khamis (2013) mentioned that the relationship between the acidic dykes and the other two groups of dykes is clear where the basic and intermediate dykes cut the acidic one.

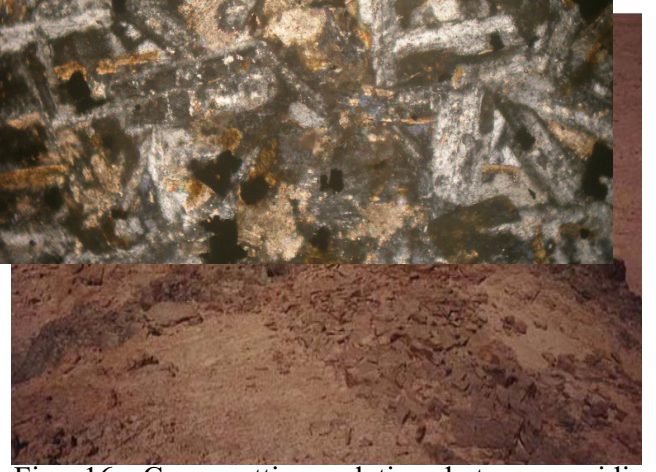

Fig. 16: Cross-cutting relation between acidic dyke (A) striking $\mathrm{N} 60^{\circ} \mathrm{W}$ (older) and basalt dyke (B) striking $\mathrm{N} 70^{\circ} \mathrm{E}$ (younger) Gabal Al Aglab area, looking $\mathrm{N}$

\section{GEOCHEMISTRY}

The study is based on 21 chemical analyses of representative rock specimens from the dyke swarms dissecting Gabal Al Aglab area. For acidic dykes, including seven samples for felsites dykes and four samples for granite porphyry one, as well as four intermediate and six basic dykes samples, are chemically 
analysed, respectively to determine the major and trace elements. The major element oxides were determined using wet chemical analysis technique (Shapiro and Brannock 1962), while the trace elements were determined using X-ray fluorescence technique (XRF). All the chemical analyses were done in the laboratories of the Nuclear Materials Authority (NMA) of Egypt.

\section{Variation in Chemical Composition}

Some major oxides and trace elements are plotted on Harker diagrams versus $\mathrm{SiO}_{2}$ as shown in Tables (1\&2) and (Figs.17-26). It is noticed from these variation diagrams that the felsite and granitic porphyry dykyes are widely separated from the intermediate and basic types, displaying two major groups.
The felsite and granitic porphyry dykes have higher values in $\mathrm{SiO}_{2}, \mathrm{~K}_{2} \mathrm{O}, \mathrm{Na}_{2} \mathrm{O}, \mathrm{Rb}, \mathrm{Zr}, \mathrm{Nb}$ and $\mathrm{Y}$ (Figs. 17-21), while they possess lower values in $\mathrm{Al}_{2} \mathrm{O}_{3}, \mathrm{TiO}_{2}, \mathrm{FeO}(\mathrm{t}), \mathrm{MgO}, \mathrm{CaO}$ and $\mathrm{Sr}$ (Figs. 22-26) than the intermediate and basic dykes. $\mathrm{SiO}_{2}$ displays positive relationship with $\mathrm{K}_{2} \mathrm{O}, \mathrm{Na}_{2} \mathrm{O}, \mathrm{Rb}, \mathrm{Zr}$, and $\mathrm{Nb}$, while it shows negative relationship with $\mathrm{Al}_{2} \mathrm{O}_{3}$, $\mathrm{FeO}(\mathrm{t}), \mathrm{MgO}, \mathrm{CaO}$ and $\mathrm{Sr}$. Also, according to Harker diagrams, in the acidic dykes, it is clear that the granite porphyry dykes are more enriched in $\mathrm{K}_{2} \mathrm{O}, \mathrm{Nb}, \mathrm{Zr}$, and $\mathrm{Rb}$, than felsites dyke while the felsites dykes are enriched in $\mathrm{Na}_{2} \mathrm{O}, \mathrm{Sr}$, and $\mathrm{Al}_{2} \mathrm{O}_{3}$ than the granite porphyry ones.

\section{Chemical Classification}

The total alkali-silica (TAS) diagram ac-

Table 1: Chemical analyses of the studied acidic (felsites and granitic porphyry) dykes, Gabal Al Aglab area

\begin{tabular}{|c|c|c|c|c|c|c|c|c|c|c|c|c|c|}
\hline \multirow[b]{2}{*}{$\begin{array}{l}\text { Sample } \\
\text { No. }\end{array}$} & \multirow[b]{2}{*}{$\mathbf{1}$} & \multirow[b]{2}{*}{2} & \multirow[b]{2}{*}{3} & \multirow[b]{2}{*}{4} & \multicolumn{3}{|c|}{ Felsite dykes } & \multirow[b]{2}{*}{ Average } & \multicolumn{4}{|c|}{ Granite porphyry dykes } & \multirow[b]{2}{*}{ Averag } \\
\hline & & & & & 5 & 6 & 7 & & 8 & 9 & 10 & 11 & \\
\hline \multicolumn{14}{|c|}{ Major oxides (wt \%) } \\
\hline $\mathrm{SiO}_{2}$ & 71.67 & 71.28 & 71.58 & 70.65 & 71.24 & 72.09 & 71.65 & 71.45 & 75.39 & 75.01 & 73.50 & $\mathbf{7 4 . 3 3}$ & 74.55 \\
\hline $\mathrm{TiO}_{2}$ & 0.15 & 0.14 & 0.09 & 0.19 & 0.18 & 0.09 & 0.17 & 0.11 & 0.07 & 0.12 & 0.14 & 0.12 & 0.11 \\
\hline $\mathbf{A I}_{2} \mathbf{O}_{3}$ & 14.45 & 14.63 & 15.26 & 15.52 & 15.65 & 14.26 & 14.02 & 14.82 & 13.36 & 14.00 & 14.03 & 13.89 & 13.82 \\
\hline FeO(t) & 1.34 & 1.08 & 1.74 & 1.28 & 1.01 & 1.54 & 1.19 & 1.31 & 1.21 & 1.08 & 1.26 & 1.23 & 1.19 \\
\hline MnO & 0.06 & 0.06 & 0.07 & 0.05 & 0.11 & 0.05 & 0.05 & 0.06 & 0.02 & 0.03 & 0.05 & 0.04 & 0.03 \\
\hline MgO & 0.06 & 0.17 & 0.11 & 0.08 & 0.16 & 0.12 & 0.08 & 0.13 & 0.12 & 0.31 & 0.26 & 0.29 & 0.24 \\
\hline $\mathrm{CaO}$ & 1.99 & 2.32 & 1.15 & 1.93 & 2.36 & 1.78 & 1.83 & 1.91 & 0.55 & 0.67 & 0.89 & 0.76 & 0.71 \\
\hline $\mathrm{Na}_{2} \mathrm{O}$ & 5.75 & 5.50 & 5.29 & 5.75 & 4.47 & 5.16 & 5.05 & 5.28 & 3.78 & 4.13 & 4.08 & 4.12 & 4.02 \\
\hline $\mathbf{K}_{2} \mathbf{O}$ & 3.01 & 3.92 & 3.61 & 3.23 & 3.88 & 4.14 & 3.73 & 3.64 & 4.85 & 4.64 & 4.76 & 4.57 & 4.70 \\
\hline $\mathbf{P}_{2} \mathbf{O}_{5}$ & 0.13 & 0.07 & 0.13 & 0.11 & 0.07 & 0.15 & 0.11 & 0.11 & 0.06 & 0.10 & 0.13 & 0.07 & 0.09 \\
\hline L.O.I & 1.26 & 0.69 & 0.23 & 0.13 & 0.69 & 1.23 & 1.68 & 0.84 & 0.46 & 0.44 & 0.94 & 0.44 & 0.57 \\
\hline Total & 99.96 & 99.93 & 99.92 & 99.91 & 99.89 & 99.72 & 99.64 & 99.75 & 99.96 & 99.97 & 99.95 & 99.97 & 99.78 \\
\hline \multicolumn{14}{|c|}{ Trace elements (ppm) } \\
\hline $\mathbf{R b}$ & 199 & 178 & 200 & 198 & 181 & 173 & 151 & 183 & 229 & 269 & 263 & 157 & 229 \\
\hline Ba & 412 & 402 & 398 & 387 & 393 & 409 & 380 & 397 & 306 & 306 & 301 & 321 & 308 \\
\hline Nb & 14 & 13 & 17 & 14 & 22 & 20 & 25 & 19 & 41 & 52 & 43 & 51 & 46 \\
\hline $\mathbf{Z r}$ & 140 & 128 & 131 & 136 & 145 & 159 & 181 & 145 & 236 & 267 & 226 & 231 & 240 \\
\hline $\mathbf{Y}$ & 24 & 25 & 24 & 20 & 28 & 23 & 31 & 25 & 27 & 25 & 27 & 24 & 25 \\
\hline $\mathrm{Cr}$ & 16 & 21 & 19 & 15 & 14 & 17 & 16 & 16 & 9 & 7.2 & 9 & 11 & 9 \\
\hline $\mathbf{Z n}$ & 30 & 33 & 29 & 22 & 31 & 37 & 34 & 31 & 50 & 46 & 39 & 44 & 44 \\
\hline Pb & 40 & 45 & 39 & 40 & 42 & 53 & 55 & 45 & 51 & 52 & 54 & 36 & 48 \\
\hline $\mathbf{U}$ & 7.4 & 7.8 & 10 & 8.0 & 8.5 & 11 & 7.7 & 8.6 & 17 & 13 & 17 & 19 & 16.5 \\
\hline Th & 13.4 & 14.0 & 16 & 13.9 & 14.7 & 16.0 & 13.6 & 14.5 & 26 & 25 & 33 & 29 & 28.2 \\
\hline $\mathbf{T h} / \mathbf{U}$ & 1.81 & 1.79 & 1.6 & 1.73 & 1.73 & 1.45 & 1.76 & 1.69 & 1.52 & 1.92 & 1.94 & 1.52 & 1.72 \\
\hline
\end{tabular}


Table 2: Chemical analyses of the studied intermediate and basic dykes, Gabal Al Aglab area

\begin{tabular}{|c|c|c|c|c|c|c|c|c|c|c|c|c|}
\hline \multirow[b]{2}{*}{ Sample No. } & \multicolumn{4}{|c|}{ Intermediate dykes } & \multirow{2}{*}{ Average } & \multirow[b]{2}{*}{16} & \multirow[b]{2}{*}{17} & \multirow[b]{2}{*}{18} & \multirow[b]{2}{*}{19} & \multicolumn{2}{|c|}{ Basic dykes } & \multirow{2}{*}{ Average } \\
\hline & 12 & 13 & 14 & 15 & & & & & & 20 & 21 & \\
\hline \multicolumn{13}{|c|}{ Major oxides (wt \%) } \\
\hline $\mathrm{SiO}_{2}$ & 57.01 & 57.90 & 58.01 & 57.80 & 57.68 & 47.22 & 48.15 & 48.63 & 49.20 & 49.32 & 48.35 & $\mathbf{4 8 . 4 7}$ \\
\hline $\mathrm{TiO}_{2}$ & 0.84 & 0.93 & 0.84 & 0.85 & 0.865 & 0.97 & 1.18 & 0.65 & 0.52 & 0.48 & 0.85 & 0.77 \\
\hline $\mathbf{A l}_{2} \mathbf{O}_{3}$ & 15.96 & 16.12 & 15.96 & 15.98 & 16.00 & 20.77 & 17.54 & 18.34 & 17.31 & 17.85 & 18.86 & 18.44 \\
\hline $\mathrm{FeO}(\mathrm{t})$ & 6.98 & 6.63 & 6.97 & 6.93 & 6.87 & 7.25 & 7.67 & 7.59 & 7.38 & 8.53 & 8.48 & 7.81 \\
\hline MnO & 0.12 & 0.19 & 0.13 & 0.14 & 0.14 & 0.12 & 0.15 & 0.12 & 0.13 & 0.25 & 0.32 & 0.18 \\
\hline MgO & 3.41 & 3.55 & 3.41 & 3.41 & 3.44 & 7.92 & 8.30 & 8.41 & 9.68 & 8.11 & 8.50 & 8.48 \\
\hline $\mathbf{C a O}$ & 6.76 & 6.50 & 6.76 & 6.77 & 6.69 & 9.23 & 10.08 & 10.91 & 10.34 & 9.65 & 9.12 & 9.88 \\
\hline $\mathrm{Na}_{2} \mathbf{O}$ & 4.41 & 3.71 & 3.46 & 3.41 & 3.74 & 3.42 & 3.13 & 2.12 & 2.75 & 2.01 & 2.15 & 2.59 \\
\hline $\mathbf{K}_{2} \mathbf{O}$ & 2.47 & 2.40 & 2.42 & 2.47 & 2.44 & 0.62 & 0.84 & 0.69 & 0.54 & 0.64 & 0.81 & 0.69 \\
\hline $\mathbf{P}_{2} \mathbf{O}_{5}$ & 0.21 & 0.27 & 0.22 & 0.21 & 0.22 & 0.11 & 0.18 & 0.08 & 0.05 & 0.12 & 0.12 & 0.11 \\
\hline L.O.I & 1.36 & 1.24 & 1.35 & 1.36 & 1.32 & 2.02 & 2.45 & 2.23 & 2.18 & 2.57 & 2.28 & 2.28 \\
\hline Total & 99.86 & 99.81 & 99.92 & 99.72 & 99.82 & 99.96 & 99.97 & 99.78 & 99.60 & 99.96 & 99.77 & 99.84 \\
\hline
\end{tabular}

Trace eiements (ppm)

\begin{tabular}{lrrrrr:rrrrrrr} 
Rb & 27 & 35 & 30 & 30 & 30 & 17 & 16 & 13 & 14 & 18 & 16 & 15 \\
Sr & 136 & 136 & 135 & 132 & 134 & 584 & 510 & 400 & 367 & 366 & 398 & 437 \\
Ba & 422 & 441 & 399 & 405 & 416 & 93 & 80 & 128 & 132 & 110 & 115 & 109 \\
Nb & 22 & 25 & 19 & 30 & 24 & 7 & 7 & 8 & 9 & 8 & 9 & 8 \\
Zr & 128 & 141 & 119 & 131 & 129 & 85 & 82 & 79 & 112 & 120 & 72 & 91 \\
Y & 15 & 17 & 22 & 18 & 18 & 12 & 15 & 14 & 16 & 22 & 12 & 15 \\
Cr & 2 & 1 & 2 & 2 & 1.75 & 95 & 108 & 122 & 106 & 82 & 47 & 93 \\
Zn & 19 & 18 & 13 & 21 & 17 & 83 & 72 & 60 & 65 & 110 & 62 & 75 \\
Pb & 12 & 15 & 16 & 17 & 15 & 7 & 8 & 6 & 7 & 17 & 32 & 12 \\
U & 2.5 & 4 & 5 & 2 & 3.37 & 2.9 & 2.5 & 3.1 & 2.8 & 3.2 & 3.0 & 2.9 \\
Th & 6.1 & 8 & 8 & 5.7 & 6.95 & 5.7 & 4.9 & 5.8 & 6.0 & 6.2 & 6.0 & 5.76 \\
Th/U & 2.44 & 2.00 & 1.650 & 2.85 & 2.23 & 1.96 & 1.96 & 1.87 & 2.14 & 1.93 & 2.00 & 1.97 \\
\hline & Intermediate dyke $:$ 人 & Basic dyke $:$ I & & & & & & &
\end{tabular}

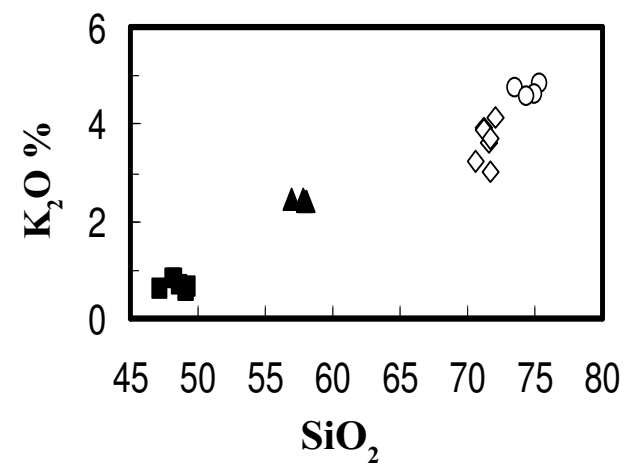

Fig. 17: Variation diagram between $\mathrm{SiO}_{2}$ and $\mathrm{K}_{2} \mathrm{O}$

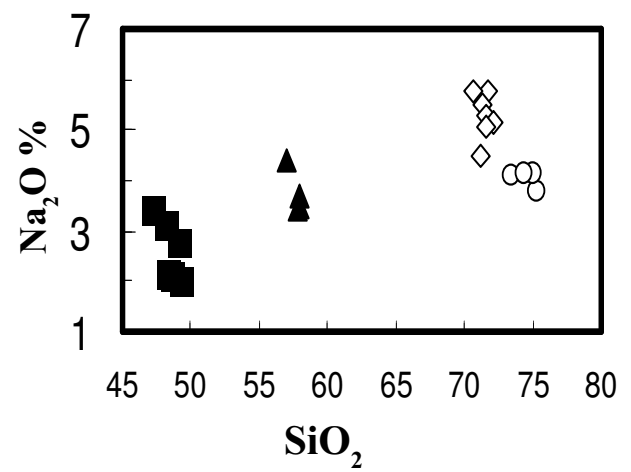

Fig. 18: Variation diagram between $\mathrm{SiO}_{2}$ and $\mathrm{NaO}_{2}$ 


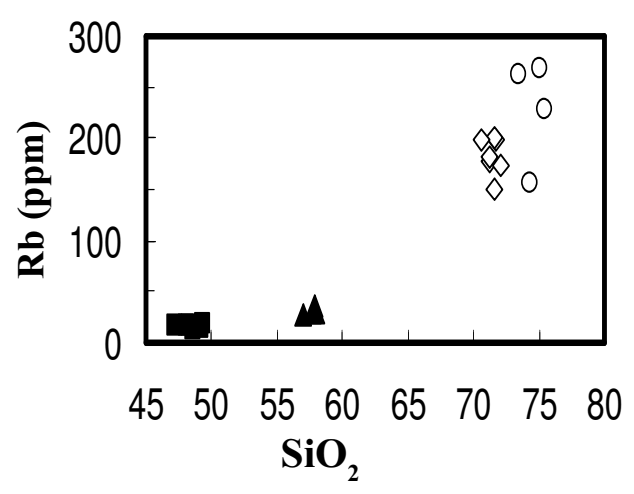

Fig. 19: Variation diagram between $\mathrm{SiO}_{2}$ and $\mathrm{Rb}$

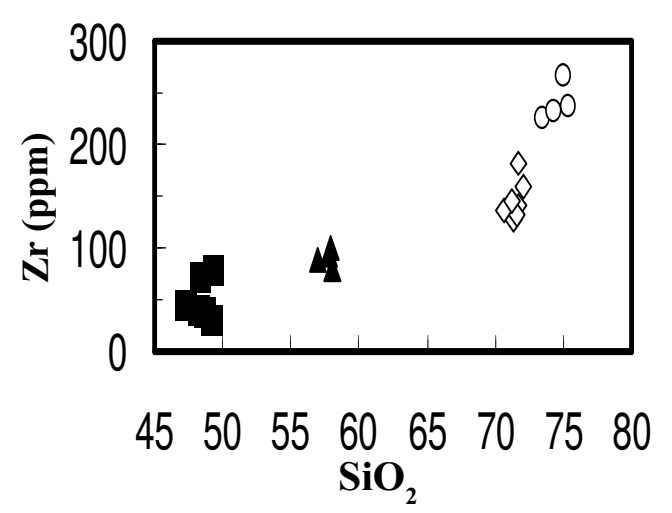

Fig. 20: Variation diagram between $\mathrm{SiO}_{2}$ and $\mathrm{Zr}$

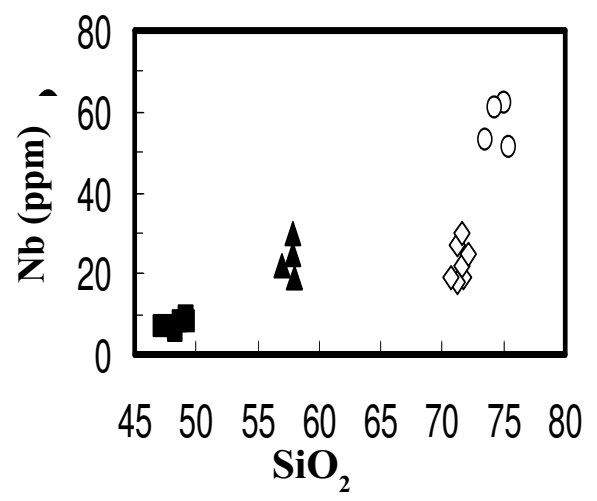

Fig. 21: Variation diagram between $\mathrm{SiO}_{2}$ and $\mathrm{Nb}$

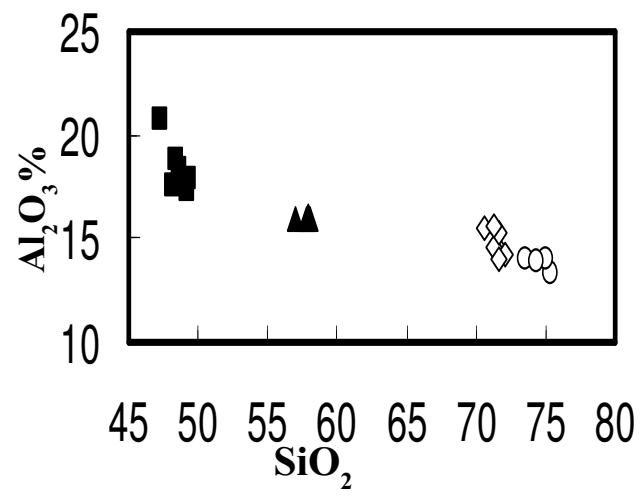

Fig. 22: Variation diagram between $\mathrm{SiO}_{2}$ and $\mathrm{Al}_{2} \mathrm{O}_{3}$.

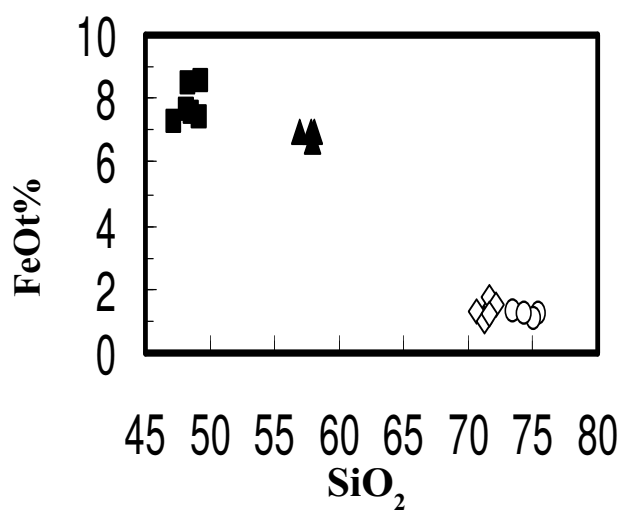

Fig. 23: Variation diagram between $\mathrm{SiO}_{2}$ and $\mathrm{FeO}(\mathrm{t})$

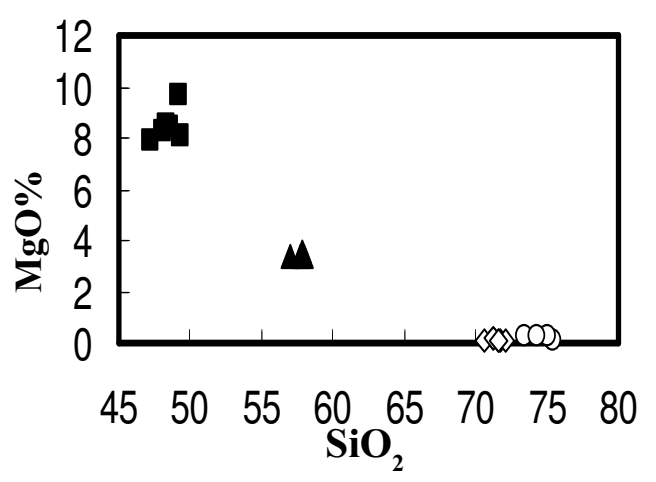

Fig. 24: Variation diagram between $\mathrm{SiO}_{2}$ and $\mathrm{MgO}$. 


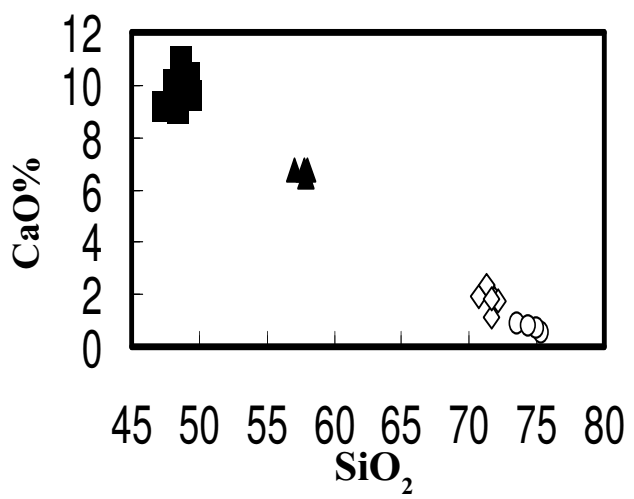

Fig. 25: Variation diagram between $\mathrm{SiO}_{2}$ and $\mathrm{CaO}$

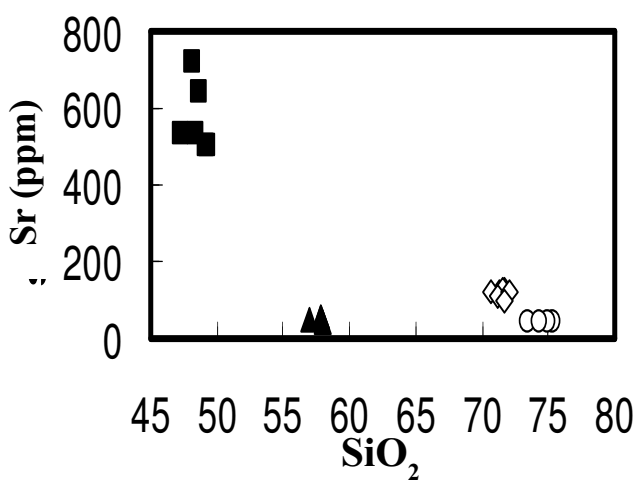

Fig. 26: Variation diagram between $\mathrm{SiO}_{2}$ and $\mathrm{Sr}$

cording to Le Maitre, 1984 (Fig.27) show that the acidic dykes (granite porphyry and felsite) plot within the rhyolite field, the intermediate dykes plot in the andesite and tracky-andesite fields while the basic dykes (basalt and dolerite) plot within the fields of basalts .

The $\mathrm{Na}_{2} \mathrm{O}$ and $\mathrm{K}_{2} \mathrm{O}$ versus $\mathrm{SiO}_{2}$ diagram according to Cox et. al. (1979) shows that the acidic dykes plot within the field of rhyolite, the intermediate dykes plot within the field andesite and tracky-andesite fields, while the basic dykes plot within the field of basalt (Fig. 28).

\section{Magma Type}

On the standard alkali-silica diagram ac-

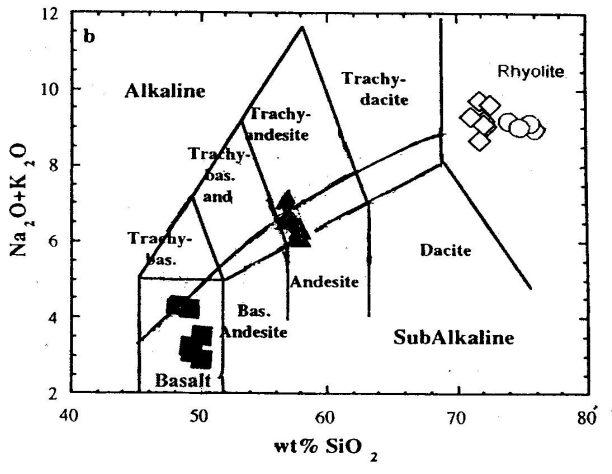

Fig. 27: $\mathrm{Na}_{2} \mathrm{O}+\mathrm{K}_{2} \mathrm{O}$ vs. $\mathrm{SiO}_{2}$ (TAS) Le Maitre (1989)

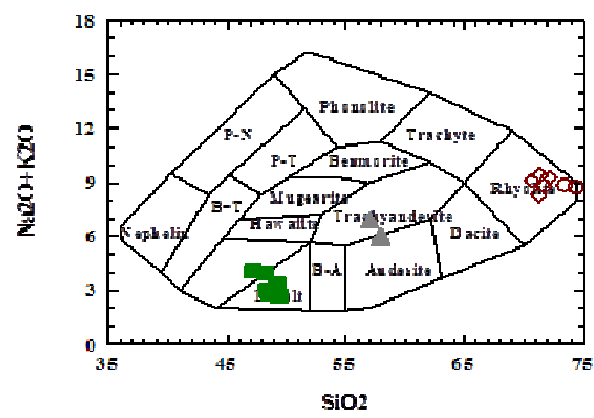

Fig. 28: $\mathrm{Na}_{2} \mathrm{O}+\mathrm{K}_{2} \mathrm{O}$ vs. $\mathrm{SiO}_{2} \mathrm{Cox}$ et. al., 1979)

cording to Irvine and Barger (1971), the acidic, intermediate and the basic dykes are located on the subalkali field (Fig.29). On the AFM diagram Irvine and Barger (1971) the intermediate and basic dykes samples are arranged along the calc-alkaline curve, while the acidic dyke samples fall near the alkali field indicating that they were derived from a highly fractionated calc-alkaline magma enriched in alkalies (Fig.30).

\section{Tectonic Setting}

On the Ti versus $\mathrm{Zr}$ diagram (Pearce and Cann, 1973) the intermediate and the basic samples except one, are plotted within the calc alkaline field (Fig. 31), and the same results are documented on the Zr-Ti-Sr ternary diagram (Pearce and Cann, 1973) (Fig.32). The samples of felsite dykes are plotted in 


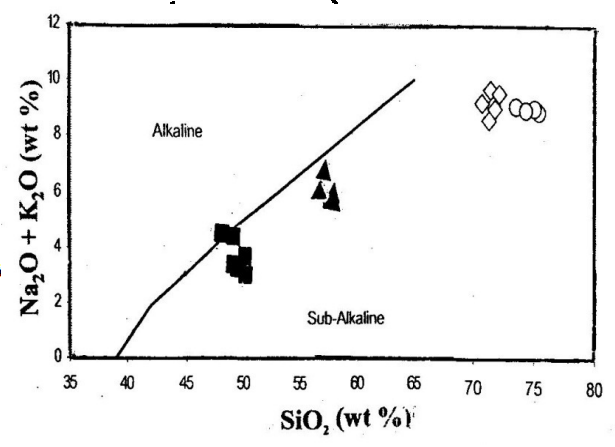

Fig. 29: $\mathrm{SiO}_{2}$ versus $\mathrm{Na}_{2} \mathrm{O}+\mathrm{K}_{2} \mathrm{O}$ variation diagram of Irvine and Baragar (1971)

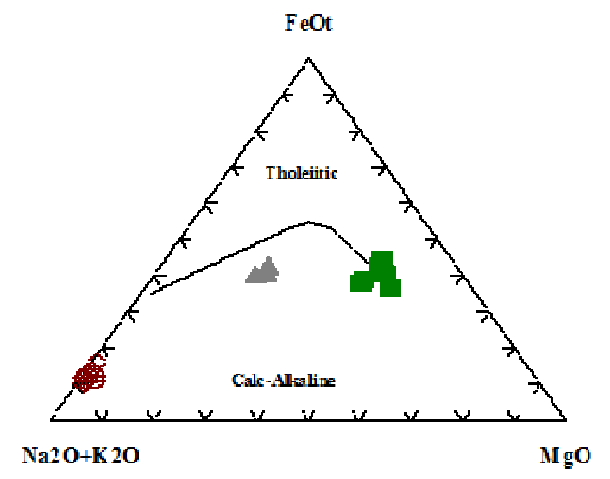

Fig. 30: AFM diagram by (Irvine and Baragar (1971)

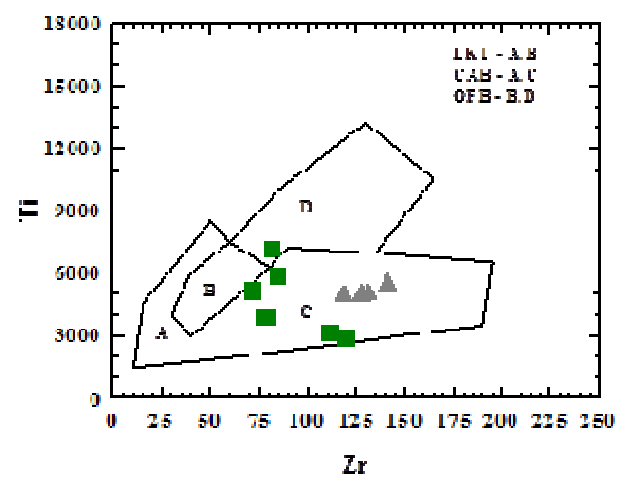

Fig. 31: Ti-Zr tectonic discrimination diagram (Pearce and Cann, 1973)

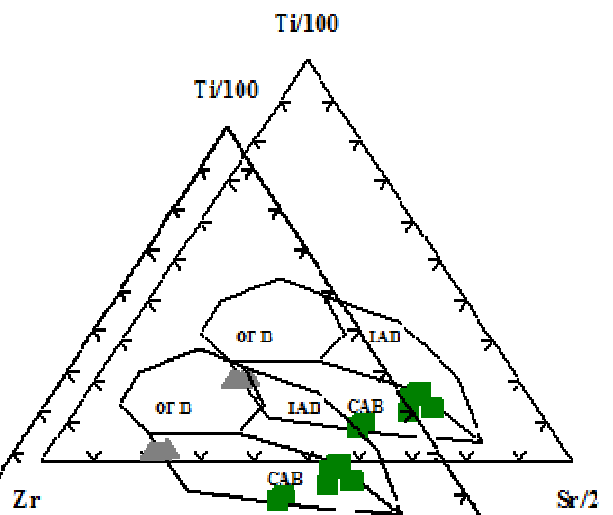

Fig. 32: $\mathrm{Zr}-\mathrm{Ti}-\mathrm{Sr} / 2$ tectonic discrimination diagram (Pearce and Cann, 1973)

volcanic arc granite fiel (VAG), while the samples of the granite porphyry dykes are plotted in within plate granites field (WPG) on $\mathrm{Rb}$ versus $\mathrm{Y}+\mathrm{Nb}$ variation diagram (Pearce et al.,1984) (Fig. 33). Finally, the studied felsites and granites porphyries as well as intermediate samples are plotted within-plate basalts field, while the basic samples (basalts and dolerites) fall in the overlapping area between mid-ocean ridge basalt and island arc basalt, except two samples are plotted totally in the island arc basalts field on the $\mathrm{Zr} / \mathrm{Y}-\mathrm{Zr}$ diagram (Pearce and Norry, 1979) (Fig.34).

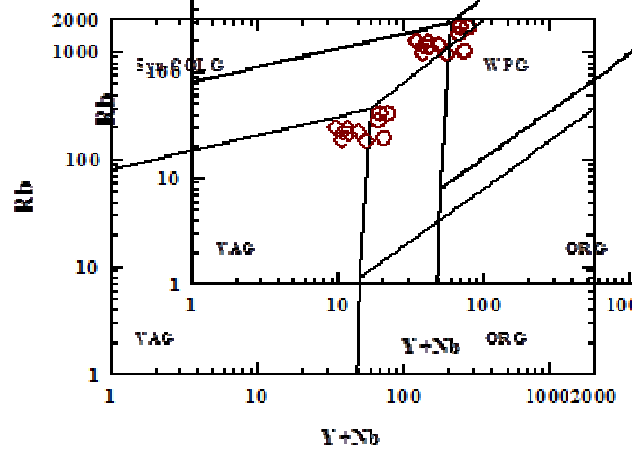

Fig. 33: $\mathrm{Rb}$ versus $\mathrm{Y}+\mathrm{Nb}$ diagram (Pearce et al., 1984) 


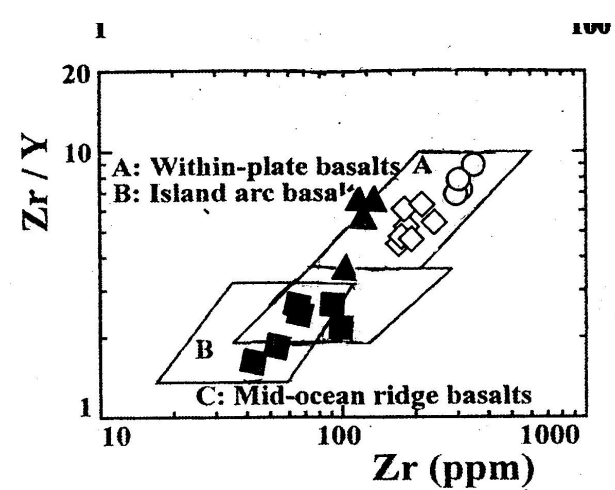

Fig. 34: $\mathrm{Zr} / \mathrm{Y}$ versus $\mathrm{Zr}$ discrimination diagram by Pearce and Norry (1979)

\section{RADIOACTIVITY}

\section{A Field Radiometric Survey}

The field radiometric survey was carried out using the portable scintillometer (UG130), measuring in terms of count per second (Cps). All measurements of total gamma radioactivity were converted into recommended radioactive unit "Ur". This unit is known as unit of radioelement concentration according to the recommendation of the International Atomic Energy Agency (IAEA, 1976). Equivalent (eU) and thorium (eTh) values were measured using the X-ray fluorescence technique (XRF). The $U$ and Th contents of the studied dyke samples were chemically determined by spectro-photometric techniques. All the chemical analyses were done in the laboratories of the Nuclear Materials Authority (NMA) of Egypt.

The investigated area is traversed by different swarms of dykes of different composition represented by acidic, intermediate and basic dykes. Each of them is characterized and identified by a certain range of radioactivity (Figs. 35-37 \& Table 3). So it is important to discuss in some details the distribution of gamma radioactivity in each type of them and determine the factors controlling the distribution of their high radioactivity values.
The acidic dykes are mainly represented by felsites and granite porphyries. Their ground radioactivity ranges from $9 \mathrm{Ur}$ to 33.5 Ur, with a mean value (X) equal 24.1 Ur (Table 3 ) and the standard deviation (S) equals 7 $\mathrm{Ur}$, which is a moderate level of radioactivity (Fig. 35).

The intermediate dykes are mainly represented by andesite and its porphyry one and are of limited distribution. Their gamma radioactivity ranges from $3 \mathrm{Ur}$ to $21 \mathrm{Ur}$, with a mean value of $14.2 \mathrm{Ur}$ and the standard deviation (S) equals $4.5 \mathrm{Ur}$ (Table 3 \&Fig. 36).

The basic dykes include both basalt and dolerite and have gamma radioactivity less than the intermediate dykes. They range in their gamma radioactivity from $3 \mathrm{Ur}$ to $18 \mathrm{Ur}$, with a mean value $(\mathrm{X})$ equal $13 \mathrm{Ur}$ (Table 3 ) and their standard deviation (S) equals 4.4 Ur, indicates a low level of radioactivity (Fig. 37).

\section{Different Ions and Radioactivity}

The interelements relation are illustrated according to $\mathrm{U}$ versus $\mathrm{SiO}_{2}$ and $\mathrm{Th}$ versus $\mathrm{SiO}_{2}$ diagrams (Fig. 38 \&39). From the variation diagrams, it depicts that the felsites and granites porphyry dykes samples being higher in both two radioactive elements, than the intermediate and basic dykes. Both dis-

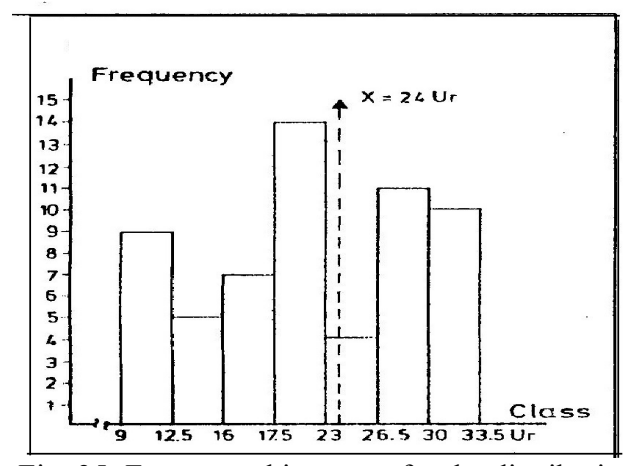

Fig. 35: Frequency histogram for the distribution of ground gamma Radioactivity of acidic dykes, Gabal Al Aglab area 
Table 3: Summary of the calculated statistical parameters for gamma Radioactivity of the various dyke types, Gabal Al Aglab area

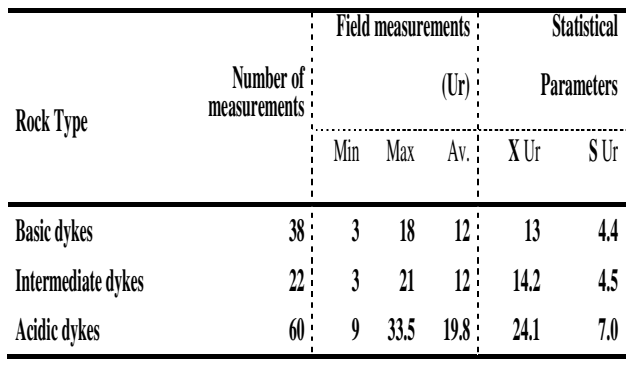

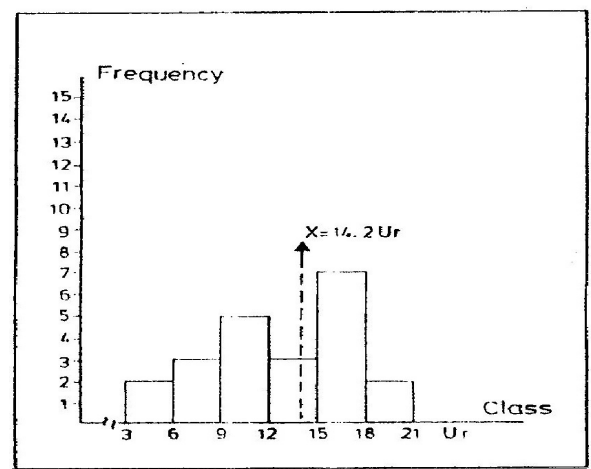

Fig. 36: Frequency histogram for the distribution of ground gamma Radioactivity of intermediate dykes, Gabal Al Aglab area

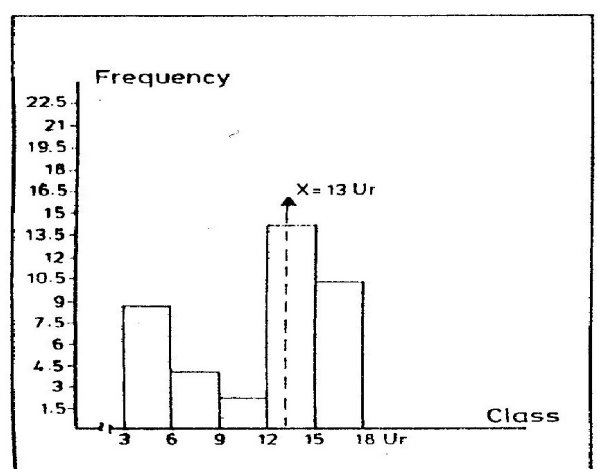

Fig. 37: Frequency histogram for the distribution of ground gamma Radioactivity of basic dykes, Gabal Al Aglab area

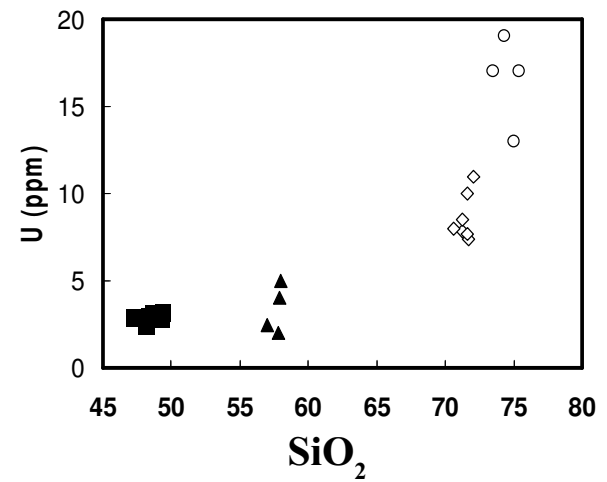

Fig. 38 : U versus $\mathrm{SiO}_{2} \%$ variation diagram

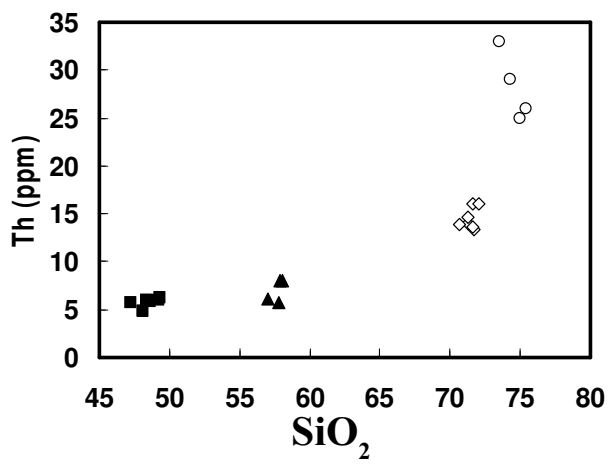

Fig. 39: Th versus $\mathrm{SiO}_{2} \%$ variation diagram

criminated diagrams show direct relationship indicating differentiation trend. The scattered pattern of the felsites and granites porphyry samples display that they are affected by post magmatic hydrothermal solutions.

\section{Radioactive Anomalies}

Generally, the local thermal effect of the basic dykes in the surrounding country rocks is well distinct around the contact. The effect of heat flow of the basic dykes during their extrusion within granites, cause redistribution of the radioactive minerals within the granites and accumulated them near the contact with the basic dykes. The emplacement of 
basalt dykes created a zone of superheating and rising the temperature of the circulating hydrothermal solutions which create a sort of convection currents (Shalaby, 1995). These solutions are rich in $\mathrm{CO}_{2}$ which could mobilize uranium as uranyl carbonates (Moreau, 1978). Hydrothermally, the altered granites provide an excellent substrate for the investigation of naturally occurring radioactivity due to its elevated level of uranium and thorium especially along faults and near the basic dykes (Morton et al, 2002).

At the northern part of the studied area, this phenomena was observed as a specific interesting radioactive anomaly, located along a small tributary branched from wadi Al Aglab (Fig. 1). The granites, at this location, show red to reddish brown color due to hematitization and exhibit a strongly sheared granitic zone. It is nearly $(0.3 \times 1.5 \mathrm{~m})$ in size and is located following a major basalt dyke striking $\mathrm{N} 50^{\circ} \mathrm{E}$, dipping $75^{\circ} \mathrm{SE}$.

The radioactive background of the granite is $16 \mathrm{Ur}$, while at the radioactive part it rises to $50 \mathrm{Ur}$ and reaches up to $55 \mathrm{Ur}$, after digging for $20 \mathrm{~cm}$. Grab sample is collected from this sheared granitic spot and radiometically analysed to give eU content $78 \mathrm{ppm}$ and $\mathrm{eTh}$ content $10 \mathrm{ppm}$. Chemical analyses of $U$ and Th contents are $17 \mathrm{ppm}$ and $26 \mathrm{ppm}$, respectively. The calculated $\mathrm{D}$-factor $=\mathrm{U} / \mathrm{eU}$ ratio is 0.22 ; this indicates a strong post-magmatic uranium mobilization in this location (Hansink, 1976).

\section{CONCLUSIONS}

The dyke swarms are intruding the Gabal Al Aglab granite pluton include acidic dykes (granitic porpgyrey and felsite), intermediate dykes (andesite and its porphyry) and basic (basalts and dolerites) dykes. The cross-cutting relations of different dyke types indicate the following sequence of emplacement beginning with the oldest as follow; acidic, intermediate and basic. During field studies, the frequency distribution and attitudes of dyke swarms show that the NE-SW and
ENE-WSW directions represent the most predominating trends of these dykes followed by the E-W and N-S. The various investigated dykes are showing as a simple, multiply, and composite shape types. Generally, the acidic dykes display more resistance to the erosion than the intermediate and basic dykes.

Petrographically, the dyke swarm under consideration could be classified into three petrographic types: acidic (felsic), intermediate and basic (mafic) dykes arranged in order of decreasing abundance. Felsites dykes are generally fine-grained to cryptocrystalline. They are chiefly composed of fine-grained holocrystalline felsitic groundmass of quartz, plagioclase and potash feldspar. Granite porphyry dykes are composed of potash feldspar, quartz and plagioclase feldspar phenocrys of variable grain size, embedded in a quartzofeldspathic groundmass. Intermediate dykes are represented by andesites and andesite porphyries essentially composed of plagioclase, hornblende, biotite with suboedinate quatz and chlorite. Basic dykes are mainly represented by basalts and dolerites. Basalt dykes are consists of plagioclase, hornblende and pyroxene. Dolerite dykes are mainly constituted of plagioclase and pyroxene with subordinate hornblende.

Geochemically, the acidic dykes including (felsites and granites porphyries) were derived from a highly differentiated calc-alkaline magma with moderate to high contents of $\mathrm{SiO}_{2}$ and Alk $\left(\mathrm{Na}_{2} \mathrm{O}\right.$ and $\left.\mathrm{K}_{2} \mathrm{O}\right), \mathrm{Zr}, \mathrm{U}$ and $\mathrm{Th}$, and poor in $\mathrm{FeO}(\mathrm{t}), \mathrm{MgO}, \mathrm{Al}_{2} \mathrm{O}_{3}, \mathrm{CaO}$ and $\mathrm{Sr}$ relative of basic and intermediate dykes. They are relatively moderate values in some trace elements (ex., Y, $\mathrm{Nb}$ and $\mathrm{Rb}$ ) exhibit a transitional position between the volcanic arc and within plate tectonic settings, while the basic and intermediate dykes have a higher values in $\mathrm{Al}_{2} \mathrm{O}_{3}, \mathrm{TiO}_{2}, \mathrm{FeO}(\mathrm{t}), \mathrm{MgO}, \mathrm{CaO}$ and $\mathrm{Sr}$, and slightly rich in both $\mathrm{Na}_{2} \mathrm{O}$ and $\mathrm{K}_{2} \mathrm{O}$ and $\mathrm{Zr}$ contents while poor in the $\mathrm{SiO}_{2}, \mathrm{Y}, \mathrm{Nb}$, $\mathrm{U}$ and $\mathrm{Th}$ values. They are slightly rich in $\mathrm{Na}_{2} \mathrm{O}, \mathrm{K}_{2} \mathrm{O}, \mathrm{Zr}$ and high $\mathrm{Sr}$ values, thus could hardly support that their magma type is sub- 
alkaline affinity and originated mainly in calc alkaline tectonic setting and shifted to within plate tectonic setting environmental character. Geochemical studies as well as the sequence of dyke emplacement indicate that the examined dykes were possibly derived from separate magmas and not by magmatic differentiation of single mother magma.

Radiometrically, the acidic dykes are higher in $\mathrm{U}$ and Th contents than the intermediate and basic dykes, through radiometric and chemicall measurements. The acidic dyke's samples are suffering from the post magmatic hydrothermal solutions effects, more than the intermediate and basic dykes.

The radioactive granitic spot in the studied area of the Gabal Al Aglab was recorded. It is related to the thermal effect of the basic dyke emplacement on the surrounding granite. The radiometric measurements of the radioactive anomaly show $\mathrm{m}$ value equal $55 \mathrm{Ur}$, after digging for $20 \mathrm{~cm}$. While radiometrically it show (eU) content $78 \mathrm{ppm}$ and eTh content $10 \mathrm{ppm}$. Chemical analyses equal $\mathrm{U}$ and $\mathrm{Th}$ contents are $17 \mathrm{ppm}$ and $26 \mathrm{ppm}$, alternatively. The calculated $\mathrm{U} / \mathrm{eU}$ ratio is 0.22 ; indicating a strong post-magmatic uranium mobilization controlling this radioactive part. According to the above discussion the thermal effect of the basalt dykes on the younger granites with its alteration and the associated highly radioactivity must be taken in consideration in future because they are favourable condition for localization of uranium mineralizations.

\section{REFERENCES}

Abu El Leil, I. 1980. Geology, petrography and geochemistry of some granitic rocks in the northern part of the Eastern Desert of Egypt. Ph.D. Thesis, Al Azhar. Uni. Egypt, $294 \mathrm{p}$.

Akkad, M. K.; Noweir, A.M., and Kotb, H., 1979. Geology and petrochemistry of the granite association of the Arabian Desert orogenic belt between latitudes 2535 and $2600 \mathrm{~N}$. Delta. J. Sci., 3, 107-151.
Amin, M.S.; Moustafa, G.A., and Zaatout, M.A., 1954. Geology of Abu Diab District. Geol., Mines and Quarries Dept., Cairo, Egypt, 24P.

Ayoub, R.R., 2003. Geology and radioactivity of Gabal Um tweir area, north Eastern Desert, Egypt. Ph. D. Thesis, Cairo Univ., Egypt, 286 p.

Cox, K.C.; Bell, J.D., and Pankhurst, R.J., 1979. The interpretation of igneous rocks. William Clowes, London, Britain, 414p.

El Ramly, M.F., and Akaad, M.K., 1960. The basement complex in the central Eastern Desert of Egypt, between Lat. 2430 and 2540 N. Geol. Sur. Cairo, 8, 35 p.

El Sawey, A.H.; Farag, S.F., and Sadek, A., 2009. Petrogensis and uranium mineralization of $\mathrm{Abu}$ Marwah A- type granite north Eastern Desert, Egypt. Geol. Surv. , XXX.1, 1-23p.

El Shazly, E. M., 1970. Evolution of granitic rocks in relation to major tectonic. The West Commemoration Volume, University of Sagar, India.

Hansink, J.D., 1976. Equilibrium analysis of a sandstone roll-front uranium deposit, In: Exploration for uranium ore deposits, IAEA, 683-693.

Irvine, T.N., and Baragar, W.R.A., 1971. A guide to the chemical classification of the common volcanic rocks. Canada. J. Earth Sci. , 8, 523 - 548 .

Kabesh, M.L., and Shahin, A.N., 1968. Preliminary studies of the dyke rocks in Ash El Mellaha range, Eastern Desert, Egypt. Egyptian G. Geol., 12 (1) , 21-32.

Khamis, H. A., 2013. Structural and radiometric studies of the Precambrian rocks at Wadi Fatira El Zarqa area, Central Eastern Desert, Egypt. Ph. D. Thesis, Cairo Univ., Egypt, 299 p.

Le Maitre, R.W.; Bateman, P.; Dudek, A.; Keller, J.; Lameyre Le Bas, M.J.; Sabine, P.A.; Schmid, R.; Sorensen, H.; Streckeisen, A.; Woolley, A.R., and Zanettin, B., 1989. A clas- 
sification of igneous rocks and glossary of terms. Blackwell, Oxford.

Mohamed, A.A.A., 2013. Mineralogical and geochemical studies of the uranium bearing granites, Gabal Abu Harba area, North Eastern Desert, Egypt. Ph.D. Thesis, Benha Uni. Egypt, 214 p.

Moreau, M., 1978. Cadre tectonomagmatique des granites uraniferes dans l'exemple de la France. COGEMA-BU/DRM, 18p.

Morton, L.S.; Evans, C.V., and Estes, G.O., 2002. Heavy metals in the environment. J. Environs. Qual., 31, 155-162.

Pearce, J.A., and Cann, J.R., 1973. Tectonic setting of basic volcanic rocks determined using trace element analyses. Earth Planet. Sci. Lett., 19, $289-300$.

Pearce, J.A.; Harris, N.B.W., and Tindle, A.G., 1984. Trace element discrimination Diagrams for the tectonic interpretation of granitic rocks. J. Petrol., 25, 956 - 983p.

Pearce, J.A., and Norry, H.J., 1979. Petrogenetic implications of $\mathrm{Ti}, \mathrm{Zr}, \mathrm{Y}$ and $\mathrm{Nb}$ variation in volcanic rocks. Contributions to Mineralogy and Petrology, 69, 33-47.

Rogers, J.J.W.; and Greenberg, J.K., 1983. Summary of recent work on Egyptian younger granites, Ann. Geol. Surv. Egypt. , 13, 185-
191.

Roz, M. E., 2001. Geology and uranium potentialities in Gabal Abu Harba environs, North Eastern Desert, Egypt. Ph. D. Thesis, Cairo Univ., Egypt, 264 p.

Shalaby, M. H., 1995. New occurrence of uranium mineralizations G VII, Gabal Qattar uranium prospect, North Eastern Desert, Egypt. Bull. Fac. Sc. Alex. Univ., 35, No. 2, 447-460 .

Shapiro, L., and Brannock, W. W., 1962. Rapid analysis of silicate, carbonate and phosphate rocks. U. S. Geol. Surv. Bull. 1144A, 56 p.

Stern, R.J., and Hedge, C.E., 1985. Geochronology and isotopic constraints on Late Precambrian crustal evolution in the Eastern Desert of Egypt. Amer. J. Sci., 285, 97-127.

Stern, R.J.; Sellers, G.; Gottfried, D., and Hedge, C.E., 1984. Late Precambrian Riftting and Crustal Evolution n North Eastern Desert of Egypt. Geology, 12, 168-172 .

Stern, R.J.; Sellers, G., and Gottfried, D., 1988. Bimodal dyke swarms in the North Eastern Desert of Egypt. In: The Pan-African Belt of Northeast Africa and adjacent areas(El Gaby, S. and Greiling, R.O., Eds), Brounschweig (Vieweg), 147-179.

\section{الدراسات الجيولوجية والبتروجرافية والجيوكيميائية والاشعاعية للسدود القاطعة لمنطقة جبل الأجلب, شمال الصحراء الشرقيةـ مصر وائهر \\ محمد محمود الضبع}

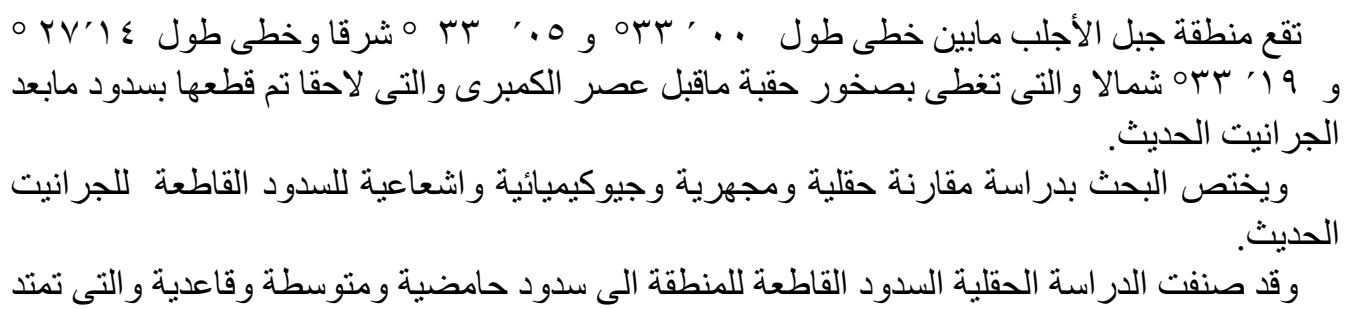


أساسا فى اتجاهات شمال شرق-جنوب غرب و شرق شمال شرق- غرب جنوب غرب وبدرجة أقل فى

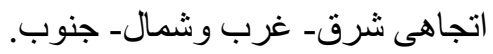

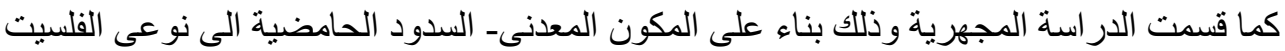
و الجر انيت البورفيرى و التى تتميز باحتو ائها على معادن الكوارتز, البلاجيوكلاز و البوتاش, والثان المتوسطة

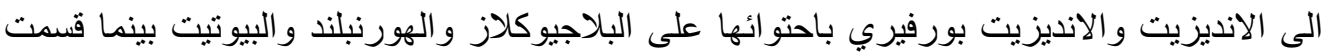

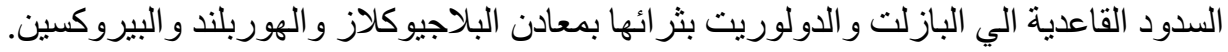

.....وقد بينت الدراسة الجيوكيميائية على غنى السدود الفلسيت و الجرانيت البورفيرى بأكاسيد

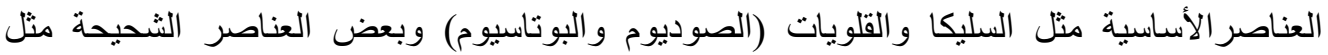

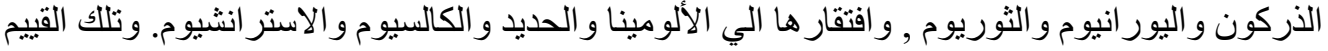

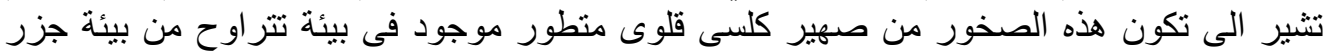

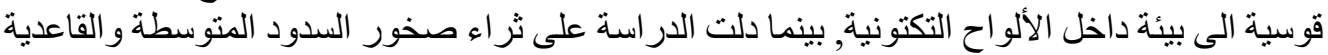

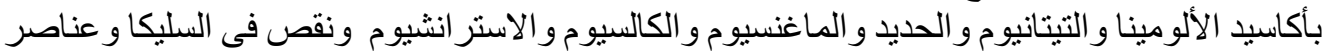

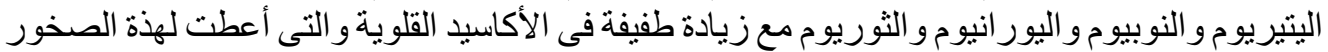

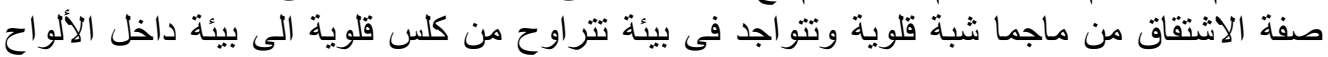

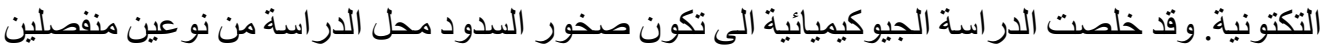

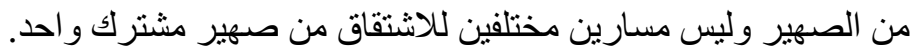

وقد أثشارت الدر اسة الاشعاعية عامة الى احتو اء السدود الحامضىة على كلى كمية من اليور انيو و والثوريوم

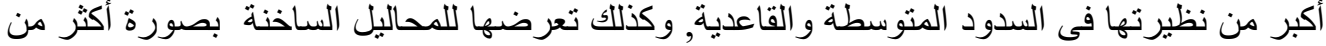

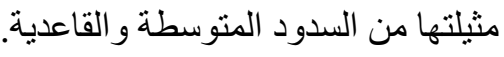

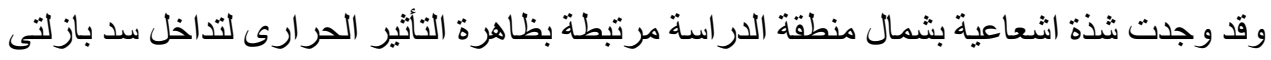

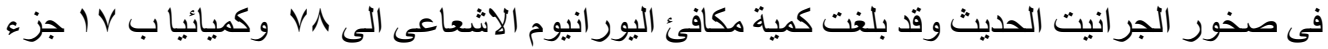

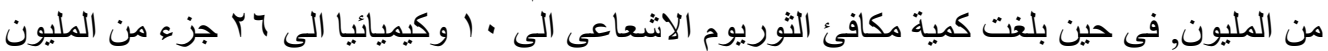

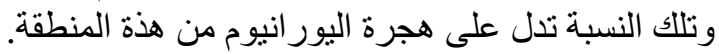

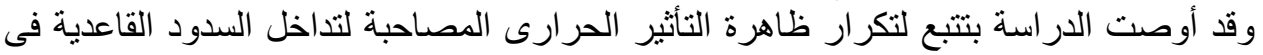
الجر انيتات الحديثة ـ كوسيلة مرشدة لاستكثاف الأماكن المحتملة لتمعدنات اليور انيوم و الثوريوم بمناطق لتئ 